\title{
Bioluminescence imaging reveals inhibition of tumor cell proliferation by Alzheimer's amyloid $\beta$ protein
} Hong Zhao ${ }^{1}$, Jinmin $\mathrm{Zhu}^{2}$, Kemi Cui ${ }^{1}$, Xiaoyin Xu' ${ }^{2}$, Megan O'Brien ${ }^{3}$, Kelvin K Wong ${ }^{1}$, Santosh Kesari ${ }^{4,5}$, Weiming Xia*3 and Stephen TC Wong ${ }^{1}$

\begin{abstract}
Address: ${ }^{1}$ Center for Biotechnology and Informatics, The Methodist Hospital Research Institute and Department of Radiology, The Methodist Hospital, Weill Cornell Medical College, Houston, Texas 77030, USA, 2Department of Radiology, Brigham and Women's Hospital, Harvard Medical School, Boston, Massachusetts 02115, USA, ${ }^{3}$ Center for Neurologic Disease, Department of Neurology, Brigham and Women's Hospital, Harvard Medical School, Boston, Massachusetts 02115, USA, 4Department of Medical Oncology, Dana Farber Cancer Institute, Harvard Medical School, Boston, Massachusetts 02115, USA and ${ }^{5}$ Department of Neurology, Brigham and Women's Hospital, Harvard Medical School, Boston, Massachusetts 02115, USA
\end{abstract}

Email: Hong Zhao - HZhao@tmhs.org; Jinmin Zhu - zhu@crystal.harvard.edu; Kemi Cui - kcui@tmhs.org; Xiaoyin Xu - xxu@bwh.harvard.edu; Megan O'Brien - meganlobrien@gmail.com; Kelvin K Wong - kwong@tmhs.org; Santosh Kesari - skesari@partners.org;

Weiming Xia* - wxia@rics.bwh.harvard.edu; Stephen TC Wong - STWong@tmhs.org

* Corresponding author

Published: I June 2009

Cancer Cell International 2009, 9:15 doi:10.1 186/1475-2867-9-15

Received: 3 February 2009

Accepted: I June 2009

This article is available from: http://www.cancerci.com/content/9/1/15

(c) 2009 Zhao et al; licensee BioMed Central Ltd.

This is an Open Access article distributed under the terms of the Creative Commons Attribution License (http://creativecommons.org/licenses/by/2.0), which permits unrestricted use, distribution, and reproduction in any medium, provided the original work is properly cited.

\begin{abstract}
Background: Cancer and Alzheimer's disease (AD) are two seemingly distinct diseases and rarely occur simultaneously in patients. To explore molecular determinants differentiating pathogenic routes towards $A D$ or cancer, we investigate the role of amyloid $\beta$ protein $(A \beta)$ on multiple tumor cell lines that are stably expressing luciferase (human glioblastoma U87; human breast adenocarcinoma MDA-MB23I; and mouse melanoma BI6F).

Results: Quantification of the photons emitted from the MDA-MB23I or BI6F cells revealed a significant inhibition of cell proliferation by the conditioning media (CM) derived from amyloid precursor protein (APP) over-expressing cells. The inhibition of U87 cells was observed only after the media was conditioned for longer than 2 days with APP over-expressing cells.
\end{abstract}

Conclusion: Our results suggest that $A \beta$ plays an inhibitory role in tumor cell proliferation; this effect could depend on the type of tumor cells and amount of $A \beta$.

\section{Introduction}

Cancer and Alzheimer's disease (AD) are the leading causes of death in the elderly. $\mathrm{AD}$ is characterized by progressive neuronal loss and associated deposition of amyloid- $\beta$ proteins (A $\beta)$ and neurofibril tangles. Glioblastoma multiforme (GBM) is the most malignant brain tumor in adults, and is one of the most devastating forms of cancer arising from dramatic proliferation and migration of tumor cells. Breast cancer is the second most fatal cancer in women, and skin cancer is the most common form of cancer. Like most diseases, the risk of getting $\mathrm{AD}$ or cancer increases with age. AD affects nearly $50 \%$ for those aged 85 years or older [1]. GBM reaches its highest levels between 65 and 85 years of age [2]. About $7 \%$ of population aged 60-79 has breast cancer, and this doubles when they reach 90 years old. In addition, it is estimated that about $50 \%$ people who live to age 65 or older have skin cancer at least once. A large population of cancer 
patients may not survive long enough to develop $\mathrm{AD}$, especially in the cases of GBM. Among survivors of breast cancer or skin cancer, it seems that they rarely develop $\mathrm{AD}$ simultaneously. In addition, cancer occurs less frequently in $\mathrm{AD}$ patients than in the general population [3-5]. While epidemiologic and genetic studies have so far failed to prove that $\mathrm{AD}$ and cancer are likely to be mutually exclusive, decreased cancer frequency in $\mathrm{AD}$ patients would suggest certain cellular mechanisms may exist to prevent the co-occurrence of cancer and $\mathrm{AD}$.

Amyloid $\beta$ protein $(A \beta)$ is generated from amyloid precursor protein (APP). APP is processed by two alternative cellular pathways. $\alpha$-Secretase is involved in nonamyloidogenic processing and cleaves APP within the A $\beta$ domain, whereby release of $A \beta$ is prevented, and soluble APPs $\alpha$ is secreted. Amyloidogenic processing is driven by $\beta$-secretase, which cleaves APP at the N-terminal site of the $\mathrm{A} \beta$ domain. Both $\alpha$ - and $\beta$-secretase cleavages produce $\mathrm{C}$ terminal stubs (termed C83 and C99, respectively) that remain inserted in the membrane and are either degraded or further processed by $\gamma$-secretase to produce the $\mathrm{p} 3$ fragment or the $A \beta$ peptide, respectively $[6,7]$.

Mounting evidence favors the amyloid cascade hypothesis that causally links AD pathological process and neuronal cell death to the aggregation and deposition of $A \beta$ [8]. It has been reported that $A \beta$ exhibits neurotoxic effect via multi-processes, and some are thought to involve generation of reactive oxygen species, alteration of intracellular calcium homeostasis and mitochondrial function, and activation of caspases [9]. Small, soluble oligomers of $A \beta$ have been linked to neuronal toxicity and synaptic failure, as increased levels of oligomeric $A \beta$ species in the media of cultured cells impaired hippocampal long-term potentiation [10].

APP processing is ubiquitous, and $A \beta$ is produced by almost all types of cells. A $\beta$ generation may be a defensive consequence of an underlying disease mechanism [9]. Ischemia, hypoglycemia and traumatic brain injury, conditions that have been shown to put neurons under metabolic stress, all up regulate APP expression in animal models and cultured cells $[11,12]$. They also re-route the metabolism of APP from the non-amyloidogenic to the amyloidogenic pathway. Inhibition of mitochondrial energy metabolism alters the processing of APP to generate amyloidogenic derivatives $[13,14]$, and oxidative stress has been shown to increase the generation of $\mathrm{A} \beta$ [15-17]. The increased expression of APP and generation of $A \beta$ under conditions of energetic stress may therefore be a response to the oxidative challenge observed in the brain in $\mathrm{AD}$ and following injury. In addition, it has been reported that APP may be related to the malignant progression of human astrocytic tumors [18], and it has been shown that intra-tumoral injection of $\mathrm{A} \beta$ potently inhibits the angiogenesis of human glioblastoma and thus inhibits the growth of the tumor [19].

To investigate whether naturally secreted $A \beta$ has any effects on tumor cell proliferation, we have taken advantage of the APP over-expressing cells that generate high levels of A $\beta$. Conditioning media (CM) from APP-expressing cells contain all kinds of component of the APP derivatives, including $A \beta$ monomers, oligomers, and soluble APPs $\alpha$ and APPs $\beta$. For A $\beta$ species, studies with any individual form of $A \beta$ are difficult, as the different forms are always in equilibrium [20].

Here we adopted the bioluminescence imaging (BLI) for cell proliferation assay. BLI is a new technology in comparison to more popular cell proliferation assays, such as MTT assay [21]. It is highly sensitive for non-invasive examination of ongoing biological processes in small animals [22]. BLI is based on the detection of visible light produced during enzyme mediated oxidation of a substrate when the enzyme is expressed as a reporter. For cellbased assay, the imaging system can accommodate up to six 96-well plates in one imaging session, so it provides an ideal high-throughput screening tool to study cell proliferation provided that the cells express the reporter enzyme luciferase.

In this study we examined the effects of $\mathrm{CM}$ containing $\mathrm{A} \beta$ from APP over-expressing cells on three tumor cell lines, i.e., human GBM, breast cancer and mouse melanoma cells. Dynamic BLI cell proliferation assay was applied to measure the proliferation of these cells that stably express firefly luciferase. $\mathrm{A} \beta$ containing $\mathrm{CM}$ were obtained from Chinese Hamster Ovarian (CHO) and human neuroblastoma SH-SY5Y cells expressing wild type APP, and human embryonic kidney 293 (HEK293) cells expressing familial AD-linked Swedish mutant APP. We found that tumor cell proliferation was inhibited after the $A \beta$ enriched $C M$ was applied. This rapid assay makes it an attractive technique for high throughput screening for anti-proliferation compounds in the future.

\section{Methods \\ Cell lines}

Three cancer cell lines derived from human glioblastoma (U87-L), breast cancer (MDA-MB231-L) and mouse melanoma (B16F-L) that stably express firefly luciferase were daily monitored by BLI. The U87-L cells were generated as described previously [23]. The coding sequences for luciferase and neomycin phosphotransferase were fused and introduced into a pMMP retrovirus. The B16F-L cells were derived from murine non brain-metastatic melanoma tumor cells transduced with a lentiviral construct containing the firefly luciferase gene and the GFP 
gene [24]. The MDA-MB231-L cells were purchased from Xenogen (Xenogen Corporation, Alameda, CA). It is derived from MDA-MB231 human adenocarcinoma cells by stable transfection of the luciferase gene under the SV40 promoter.

CHO cells expressing wild type APP (7W), SH-SY5Y cells expressing wild type APP (SKAPP), HEK293 cells expressing human soluble APPs $\alpha$ (hAPPs) and HEK293 expressing familial AD-linked Swedish mutant APP (SW293) have been characterized previously [25-28]. The $\mathrm{CHO}$, SH-SY5Y and HEK293 cells expressing endogenous APP were used as controls.

All cells were grown in DMEM (InVitrogen) medium supplemented with $10 \%$ fetal bovine serum (Sigma), 2 $\mathrm{mmol} / \mathrm{L}$ L-glutamine (InVitrogen), 100 units/ml penicillin/streptomycin (InVitrogen), and in a humidified atmosphere at $37^{\circ} \mathrm{C}$ in $5 \% \mathrm{CO}_{2}$.

\section{Media replacement}

The U87-L, MDA-MB231-L, B16F-L cells (500 cells/well) and the 7W, CHO, SKAPP, SH-SY5Y, SW293, HEK293 and hAPPs, HEK293 cells (1000 cells/well) were seeded in separate 96 well plates. The $\mathrm{CM}$ from $7 \mathrm{~W}, \mathrm{CHO}, \mathrm{SKAPP}$, SH-SY5Y, SW293, HEK293 and hAPPs, HEK293 cells were harvested at $36 \mathrm{hr}, 60 \mathrm{hr}$ and $84 \mathrm{hr}$ after being planted. Media from the tumor cells was removed and replaced with fresh CM. Tumor cells with the CM were monitored for $24 \mathrm{hr}$ to $72 \mathrm{hr}$ by BLI.

\section{$A \beta$ assay by ELISA}

The A $\beta$ levels in CM were measured before media replacement. $A \beta$ sandwich ELISAs were performed as described [29]. $A \beta_{40}$ and $A \beta_{42}$ levels were measured using a standard sandwich ELISA assay where $2 \mathrm{G} 3$ (to A $\beta$ residues 33-40) and 21F12 (to A $\beta$ residues 33-42) antibodies captured $A \beta_{40}$ and $A \beta_{42}$, respectively, and biotinylated 266 antibody was used for detection.

\section{Quantification of the number of viable cells by bioluminescence assay}

To eliminate the difference in the level of luciferase expression in each cell line, calibration of photon flux with respect to actual cell count was performed. MDAMB231-L, B16F-L, and U87-L cells in $100 \mu \mathrm{L}$ media were seeded into a 96 well plate by serial dilutions from 51,200 cells to 50 cells per well, each repeated with 3 independent experiments. The plate was imaged using the IVIS 100 system ( 2 min, 8 bin, and level B/FOV $15 \times 15 \mathrm{~cm}$ ) (Xenogen Corporation, Alameda, CA) at 10 minutes after addition of luciferin at the final concentration of $150 \mu \mathrm{g} / \mathrm{mL}$. Media without luciferin were served as negative control. The photon flux was linearly regressed on the actual cell count to obtain a calibration curve for each cell line, as previously reported [30].
The baseline of the tumor cell proliferation was obtained by BLI assay $12 \mathrm{hrs}$ after cells were planted. Lights emitted from tumor cells were acquired until $72 \mathrm{hr}$ post media replacement with $24 \mathrm{hr}$ interval. An average of 3 kinetic bioluminescent acquisitions was obtained within $10 \mathrm{~min}$ utes for each acquisition time point. Regions of interest (ROI) were drawn over wells automatically and quantified by Living Image Software version 2.20. Data was analyzed based on total photon flux emission (photons/s) subtracted by the background photon flux of each well for the dark current measurement.

\section{Statistical analysis}

SPSS10.0 software was used for the statistical analysis. Data was obtained from three independent experiments with duplicate determinations and expressed as means \pm SEM (standard error of the means). Statistical analysis was performed by one-way ANOVA followed by Fisher's posthoc test procedure for significance $(P<0.05)$.

\section{Results}

\section{Stable expression of luciferase in U87-L, MB-23I-L and BI 6F-L cells}

To quantify the cell proliferation based on the detected photons from the living cells, we have determined the correlation between the number of U87-L, MDA-MB231-L and B16F-L cells and the expression levels of luciferase using BLI assay. Our BLI apparatus reaches a sensitivity of detecting about 20 MDA-MB231-L cells. Due to different expression levels of luciferase gene and morphological appearance of cell types, as low as 80 to 110 of U87-L and B16F-L cells could be detected by our BLI apparatus. When cells were seeded at higher density, there was no saturation of signals using the above imaging parameters. A positive linear correlation between the cell numbers and the BLI signals was obtained, and all three cell lines have demonstrated clear correlation, i.e., $\mathrm{R}^{2}=0.9779-0.9984$ (Fig. 1). Therefore, it is reliable to quantify the number of viable cells and cell proliferation based on the photon emission detected by BLI.

\section{Conditioning media from APP over-expressing $\mathrm{CHO}$ cells reduced the proliferation of MB-23I-L cells}

To explore any molecular determinants that differentiate pathways leading to $\mathrm{AD}$ versus cancer, we explore the role of the key peptide found in the brains of $\mathrm{AD}$ patients, $\mathrm{A} \beta$, which secretes from different types of cells and aggregates into extracellular neuritic plaques. Instead of using synthetic $A \beta$ peptide, we used naturally secreted $A \beta$ in the conditioning media (CM) from three types of cells $(\mathrm{CHO}$, HEK293 and SH-SY5Y) to treat tumor cells and searched for any inhibitory effect on cell proliferation.

We conditioned APP-over-expressing cells (7W cells) and its parental cell line $\mathrm{CHO}$ cells for $36 \mathrm{hrs}$, and harvested $\mathrm{A} \beta$-rich 7W CM and control $\mathrm{CHO} \mathrm{CM}$, then applied them 
A

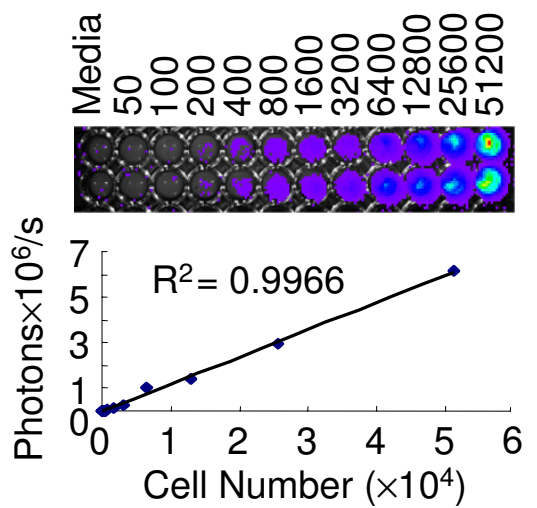

$B$
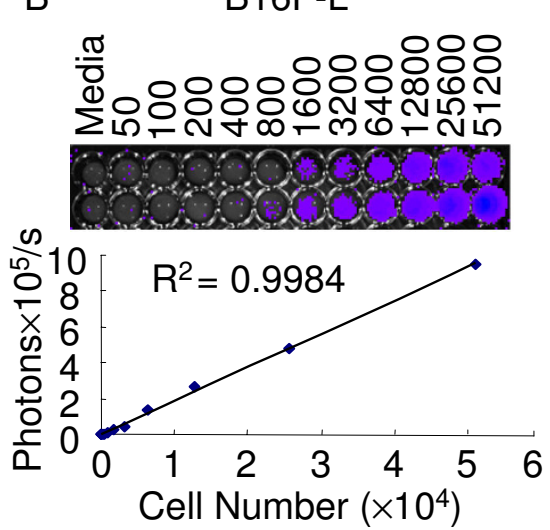

C

U87-L

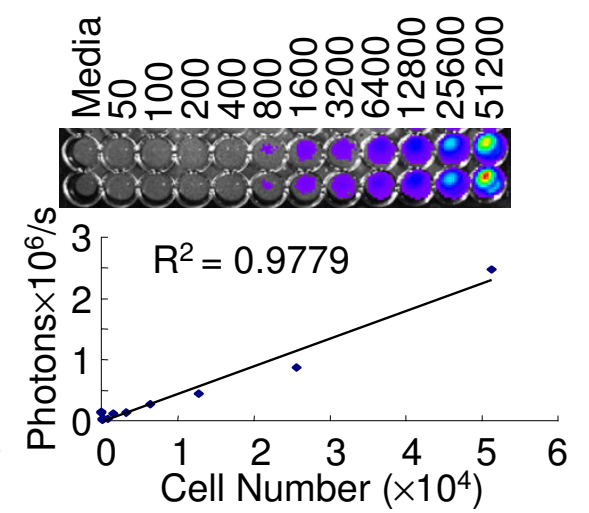

Figure I

Quantification of MDA-MB23 I-L, B I6F-L and U87-L cell proliferation by bioluminescent imaging (BLI) assay. MDA-MB23I-L (A), BI6F-L (B) and U87-L (C) cells in $100 \mu \mathrm{L}$ media were seeded into a 96 well plate by serial dilutions from $5 I, 200$ cells to 50 cells per well. The plate was imaged using the IVIS system $(2 \mathrm{~min}, 8 \mathrm{bin}$, and level B/FOV I5 $\times 15 \mathrm{~cm})$ at 10 minutes after the addition of luciferin to final concentration of $150 \mu \mathrm{g} / \mathrm{mL}$. Medium without luciferin was served as a negative control. A linear correlation between cell number and bioluminescent signal was obtained.

to 6 wells of adenocarcinoma MDA-MB231-L cells, respectively (Fig. 2A, top panel $\mathrm{CHO}$ CM, lower panel 7W $\mathrm{CM})$. The effect of $\mathrm{A} \beta$ on tumor cell proliferation was measured by BLI (Fig. 2A). After incubation for 24 hr, conditioning media from $7 \mathrm{~W}$ cells significantly delayed MDA-MB231-L cell proliferation compared to media from control CHO cells $(\mathrm{P}<0.05)$ (Fig. $2 \mathrm{~B})$. When we continued to incubate tumor cells with $\mathrm{CM}$ from $\mathrm{CHO}$ or $7 \mathrm{~W}$ cells for $48 \mathrm{hrs}$, the number of MDA-MB231-L cells incubated with CM from $7 \mathrm{~W}$ cells was significantly lower than those incubated with control CHO CM (Fig. 2C). Extended incubation up to $72 \mathrm{hr}$ further decelerated cell proliferation, resulting in about $50 \%$ reduction in the number of cells grown in 7W CM, compared to those in CHO CM (Fig. 2C). Together, these results suggested that $\mathrm{CM}$ from $7 \mathrm{~W}$ cells reduced the proliferation of MDAMB231-L cells.

\section{Inhibitory effect was independent of tumor cell types}

To determine whether the inhibitory effect of the CM from $7 \mathrm{~W}$ cells depends on the type of the tumor cell, we used a second cancer cell line: melanoma B16F-L. We conditioned $7 \mathrm{~W}$ and $\mathrm{CHO}$ cells for $36 \mathrm{hr}$. After CM from $7 \mathrm{~W}$ or $\mathrm{CHO}$ cells were applied to B16F-L cells and incubated for an extended period, we found a similar, but less dramatic effect on cell proliferation, as measured by BLI assay (Fig. 2D). At $24 \mathrm{hr}$ post media replacement, the number of B16F-L cells grown in the CM from $7 \mathrm{~W}$ cells was $50 \% \pm$ $9 \%$ of those grown in $\mathrm{CHO}$ control media (Fig. 2D), while the number of MDA-MB231-L cells grown in the CM of $7 \mathrm{~W}$ was $69 \% \pm 5 \%$ of those grown in CHO CM (Fig. $2 \mathrm{C}$ ).
At $48 \mathrm{hr}$ post medium replacement, numbers of B16F-L and MDA-MB231-L cells grown in 7W CM were $59 \% \pm$ $6 \%$ and $59 \% \pm 4 \%$ of those with $\mathrm{CHO} \mathrm{CM}$, respectively (Fig. 2C and 2D). The delay in cell proliferation was continued to $72 \mathrm{hr}$ post medium replacement, when the number of cells in the presence of 7W CM was about $64 \%$ $\pm 7 \%$ and $47 \% \pm 5 \%$ of those with CHO CM (Fig. $2 \mathrm{C}$ and 2D). Therefore, the CM from APP over-expressing $7 \mathrm{~W}$ cells decelerated proliferation of both adenocarcinoma and melanoma cells, suggesting that the inhibition was independent of tumor cell types.

\section{Cell media conditioned for extended period had greater inhibitory effect on tumor cell proliferation}

Since more $A \beta$ is secreted into the $C M$ with longer incubation time [31], we tested whether the media conditioned for a longer period would result in greater effect on tumor cell proliferation. In addition to $36 \mathrm{hr}$ incubation period, we cultured 7W and CHO cells for $60 \mathrm{hr}$ and $84 \mathrm{hr}$ (conditioning times) then collected CM. Next, we applied the CM to MDA-MB231-L or B16F-L cells and incubated for $24 \mathrm{hr}$ (incubation time) before acquiring images by BLI (Fig. 3A). For the MDA-MB231-L cells, the CM conditioned for $60 \mathrm{hr}(60 \mathrm{hr}-\mathrm{CM})$ showed stronger inhibitory effect than the $36 \mathrm{hr}-\mathrm{CM}(\mathrm{P}<0.05)$, and the $84 \mathrm{hr}-\mathrm{CM}$ showed the strongest inhibitory effect compared to the 36 hr- and 60 hr-CM $(\mathrm{P}<0.05)$ (Fig. $3 \mathrm{~A}$ and $3 \mathrm{~B})$. For the B16F-L cells, both $60 \mathrm{hr}-\mathrm{CM}$ and $84 \mathrm{hr}-\mathrm{CM}$ showed stronger inhibition compared to $36 \mathrm{hr}-\mathrm{CM}(\mathrm{P}<0.05)$, but no significant difference was observed between the $60 \mathrm{hr}$ and $84 \mathrm{hr}$-CM (Fig. 3C). Taken together, these results indi- 
A

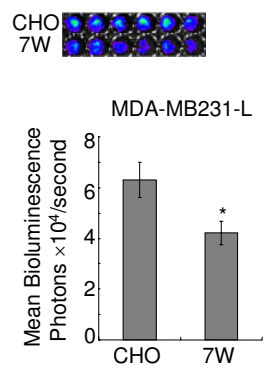

C

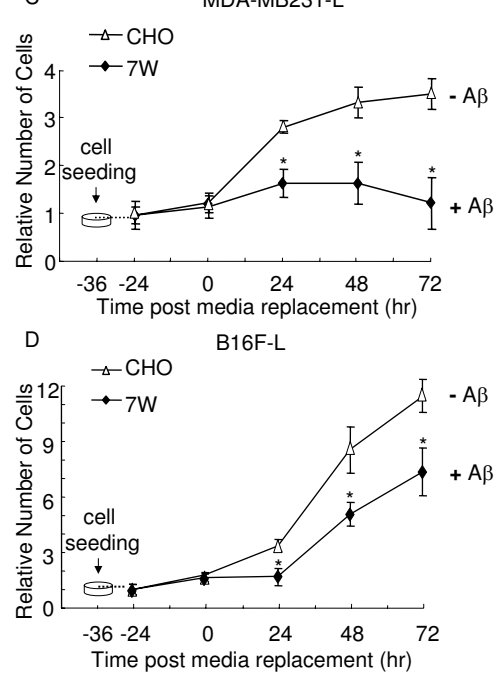

Figure 2

Media from APP over-expressing $\mathrm{CHO}$ cells suppress MDA-MB23 I-L and B I 6F-L cell proliferation. MDAMB23I-L and BI6F-L cells (500 cells/well), APP overexpressing $\mathrm{CHO}$ cells (7W cells) and $\mathrm{CHO}$ cells ( 1000 cells/ well) were seeded in 96 well plates. After $36 \mathrm{hr}$, media of MDA-MB23I-L and BI6F-L cells were replaced with the media from 7W or $\mathrm{CHO}$ cells. Proliferation of the MDAMB23I-L and BI6F-L cells was measured by BLI assay at 24 hr post medium replacement. (A) A representative image from MDA-MB23 I-L cells cultured with conditioning media (CM) from $\mathrm{CHO}$ cells $(\mathrm{CHO}-\mathrm{CM}$ ) or from $7 \mathrm{~W}$ cells $(7 \mathrm{~W}$ CM) for $24 \mathrm{hr}$. 7W-CM and control CHO-CM were applied to 6 wells of adenocarcinoma MDA-MB23 I-L cells, respectively (top panel CHO-CM, lower panel 7W-CM). (B) Mean values from three independent experiments were obtained, and media from 7W cells showed inhibition of MDA-MB23 I$\mathrm{L}$ proliferation, compared to media from $\mathrm{CHO}$ cells. The standard error of means (SEM) was illustrated $(n=12)$, and the asterisk indicates a statistically significant difference between two groups $(P<0.05$, one-way ANOVA followed by Fisher's post-hoc test). (C) Persistent inhibitory effect of CM from $7 \mathrm{~W}$ cells on MDA-MB23I-L cell proliferation. The proliferation of the MDA-MB23 I-L cells was measured by BLI assay at 24, 48 and $72 \mathrm{hr}$ post medium replacement. The photon counts at $24 \mathrm{hr}$ before medium replacement $(-24 \mathrm{hr})$ were used as the baseline for the calculation of relative cell numbers. All values indicate means $\pm \operatorname{SEM}(n=6)$, and significant difference between $\mathrm{CM}$ from $7 \mathrm{~W}$ and control $\mathrm{CHO}$ cells is indicated by $* P<0.05$. (D) Inhibitory effect of media from APP over-expressing CHO cells on melanoma (BI6F-L) cell proliferation. BI6F-L cells were quantified by $\mathrm{BLI}$ assay at 24,48 and $72 \mathrm{hr}$ after incubation with CM from $7 \mathrm{~W}$ or $\mathrm{CHO}$ cells. All values represent means $\pm \operatorname{SEM}(n=6)$, and CM from 7W cells showed significant difference in it ability to inhibit BI6F-L cell proliferation compared to CM from control $\mathrm{CHO}$ cells, as indicated by $* P<0.05$.

cate that more $A \beta$ accumulated in media conditioned for an extended period had greater inhibition on proliferation of tumor cells.

\section{Source of cells for preparing conditioning media was not cell type specific}

In order to determine whether $A \beta$ from other cell types had similar effects, media from the APP over-expressing human neuroblastoma SH-SY5Y cells (SKAPP cells) and its parental cell line SH-SY5Y were used for the incubation with tumor cells. After SKAPP and SH-SY5Y cells were grown for $36 \mathrm{hrs}$ (conditioning time), CM was collected and applied on tumor cells for 24,48 and $72 \mathrm{hr}$, followed by BLI acquisition. Apparently, there was a delay in cell proliferation in the presence of CM from SKAPP cells during the incubation period from 24 to $72 \mathrm{hrs}$. While the number of cells grown in the CM of SKAPP cells was statistically lower than those in the CM of SH-SY5Y cells, the difference in the number of MDA-MB231-L cells (Fig. 4A) was slightly larger than those of B16F-L cells (Fig. 4B). This is consistent with the previous observation with the CM from $7 \mathrm{~W}$ and $\mathrm{CHO}$ cells (Fig. 2C and 2D).

Similarly, when we extended the conditioning time to 60 and $84 \mathrm{hrs}$, we found that CM from SH-SY5Y cells acted almost identically to the CM from CHO cells. The $60 \mathrm{hr}$ and $84 \mathrm{hr}$-CM from SKAPP cells showed stronger inhibition effect on cell proliferation of MDA-MB231-L and B16F-L cells than 36 hr-CM $(\mathrm{P}<0.05)$, but no significant difference was observed between the media conditioned for $60 \mathrm{hr}$ and $84 \mathrm{hr}$ (Fig. 4C and 4D). This is highly similar to B16F-L cells grown in the CM from 7W cells (Fig. 3C).

\section{Soluble APP in conditioned media failed to inhibit cell proliferation}

The major components secreted from APP over-expressing cells include A $\beta$ as well as soluble APP (APPs $\alpha$ and APPs $\beta$ ). The majority of soluble APP is APPs $\alpha$, which derives from $\alpha$-secretase cleavage of APP; only very low levels of APPs $\beta$ (derived from $\beta$-secretase cleavage of APP) exist in the CM. Therefore, we searched for any inhibitory effect on tumor cell proliferation by APPs $\alpha$. Taking advantage of stable HEK293 cell line overexpressing soluble APPs $\alpha$, hAPPs, we cultured hAPPs cells and its parental cell line HEK293. Because the $\alpha$-secretase cleaves in the middle of $A \beta$ region, thus precluding the generation of $A \beta$, only endogenous levels of $A \beta$ are generated in hAPPs cells, and levels of $A \beta$ in CM from hAPPs expressing cells were undetectable by our ELISA (data not shown). When we conditioned media from hAPPs and HEK293 cells for 36 hr and applied CM to MDA-MB231-L and B16F-L cells for 24, 48 and 72 hrs, no inhibitory effects were observed (Fig. 5A and 5B). Therefore, high levels of APPs $\alpha$ did not affect the cell proliferation. 
A

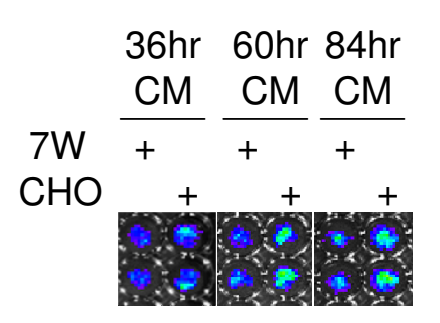

B

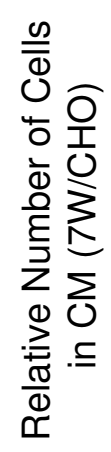

MDA-MB231-L

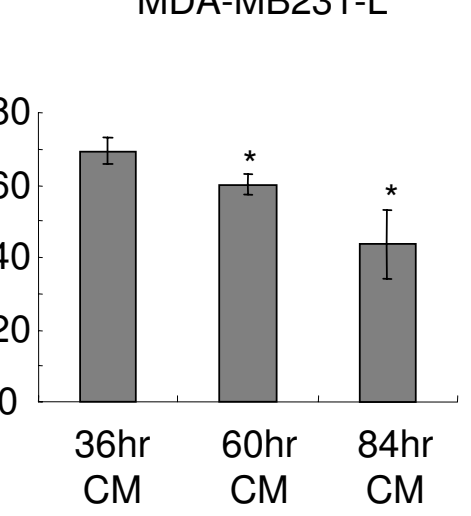

C

$\frac{\infty}{\overline{0}}$

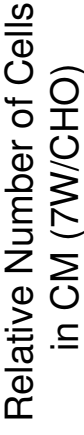

B16F-L

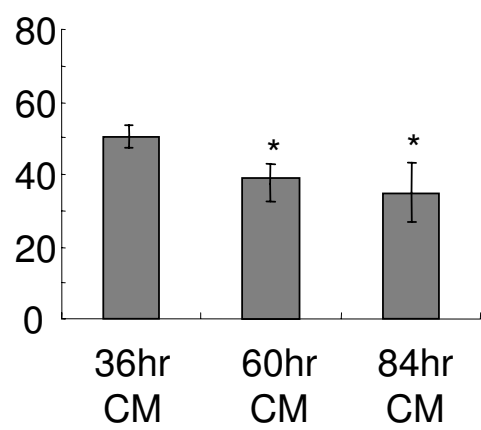

Figure 3

Media conditioned for extended period with APP over-expressing CHO cells have greater inhibitory effect on tumor cell proliferation. MDA-MB23I-L cells, BI6F-L cells (500 cells/well), 7W and CHO cells (I000 cells/well) were seeded in separate 96 well plates. 7W and control CHO cells were grown for $36 \mathrm{hr}, 60 \mathrm{hr}$ and $84 \mathrm{hr}$ before the media were harvested for incubation with tumor cells. The number of tumor cells was measured by BLI assay at 24 hr post medium replacement. (A) A representative image of MDA-MB23I-L cells was acquired at $24 \mathrm{hr}$ after the media were replaced with media conditioned with $\mathrm{CHO}$ or $7 \mathrm{~W}$ cells for 36,60 or $80 \mathrm{hr}$. (B) The relative number of cells grown in CM from $7 \mathrm{~W}$ vs. $\mathrm{CHO}$ was calculated by dividing MDA-MB23I-L cells grown in 7W-CM by those in CHO-CM. The values represent means \pm $\operatorname{SEM}(n=6)$, and the difference is statistically significant compared to cells in $36 \mathrm{hr}-\mathrm{CM}$, as indicated by $* P<0.05$.

Inhibitory effect on tumor cell proliferation correlates with $A \beta$ concentrations in conditioning media

To validate that $A \beta$ in the $C M$ delayed the proliferation of these tumor cells, we measured $A \beta 40$ and $A \beta 42$ concentrations in the CM from all cell lines. We found that both $7 \mathrm{~W}$ and SKAPP secreted similar amount of $\mathrm{A} \beta$ into the CM. Therefore, we used a third cell line, a HEK293 cell line over-expressing familial AD-linked Swedish mutant APP (SW293). It has been reported that SW293 cells secrete very high levels of $A \beta$ to the CM [28]. Clearly, within $36 \mathrm{hr}$, much more $A \beta 40$ and $A \beta 42$ were secreted into the CM from SW293 cells than those from 7W and SKAPP cells (Fig. 6A and 6B), and A $\beta$ levels increased significantly upon prolonged conditioning for $60 \mathrm{hr}$ (Fig. 6A and $6 B$ ). The amount of $A \beta 40$ and $A \beta 42$ in the $C M$ from SW293 cells continued to increase and maintained at high levels when cells were conditioned to $84 \mathrm{hr}$, but the levels of $\mathrm{A} \beta$ in the $\mathrm{CM}$ from $7 \mathrm{~W}$ and SKAPP cells started to decrease when conditioning was extended to 84 hrs (Fig. $6 \mathrm{~A}$ and $6 \mathrm{~B}$ ), partially due to a potential degradation and/ or aggregation of $A \beta$ peptide, where our ELISA only measures soluble monomeric $A \beta$.

Similar to the findings that $A \beta 40$ and $A \beta 42$ concentrations in the CM from the SW293 cells were significantly higher than those from 7W and SKAPP cells (Fig. 6A, B and 6C), the inhibitory ability of CM from SW293 cells on MDA-MB231-L and B16F-L cells was stronger than those of 7W and SKAPP cell CM. Compared with HEK293 CM treated cells, the number of MDA-MB231-L and B16F-L cells were much less after $24 \mathrm{hr}$ incubation in the $36 \mathrm{hr}$ CM from SW293 cells $(68 \% \pm 2 \%$ and $49 \% \pm 4 \%$, respectively). Longer periods of incubation up to $72 \mathrm{hr}$ also showed reduced cell numbers to $41 \% \pm 3 \%$ and $31 \% \pm$ $3 \%$, respectively (Fig. 6D, E and 6F).

\section{High levels of $A \beta$ were necessary to inhibit the proliferation of human neuroblastoma cells (U87-L)}

Apparently, both MDA-MB231-L and B16F-L were very sensitive to $A \beta$ in the $C M$. Next, we examined a cell line that seemed to be less sensitive to $A \beta$ in the $C M$, human glioblastoma, U87-L. When BLI was used to monitor the proliferation of U87-L upon the incubation of cells in the $\mathrm{CM}$ from 7W and SKAPP cells, no inhibitory effects were observed because these cells produced relatively low $\mathrm{A} \beta$ compared to SW293 cells (Fig. 7A and 7B). However, we found a significant delay in cell proliferation by the SW293 CM that was conditioned for $60 \mathrm{hr}$ or $84 \mathrm{hr}$ (Fig. 7C). We did not observe much inhibitory effect by the $\mathrm{CM}$ conditioned for $36 \mathrm{hr}$, consistent with the fact that the $\mathrm{A} \beta 40$ and $\mathrm{A} \beta 42$ levels of the $60 \mathrm{hr}-\mathrm{CM}$ and $84 \mathrm{hr}-\mathrm{CM}$ are two to five fold greater than that in the $36 \mathrm{hr}-\mathrm{CM}$ from SW293 cells (Fig. 6A and 6B). These results indicate that inhibitory ability of the $\mathrm{CM}$ correlated to the concentration of $A \beta$ levels.

\section{Surface plots of tumor cell proliferation versus the concentration of $A \beta 40$ and $A \beta 42$ in the conditioning media Finally, we plotted the cell proliferation of the three tumor cell lines as a function of the $A \beta$ concentration (Fig. 8). We}



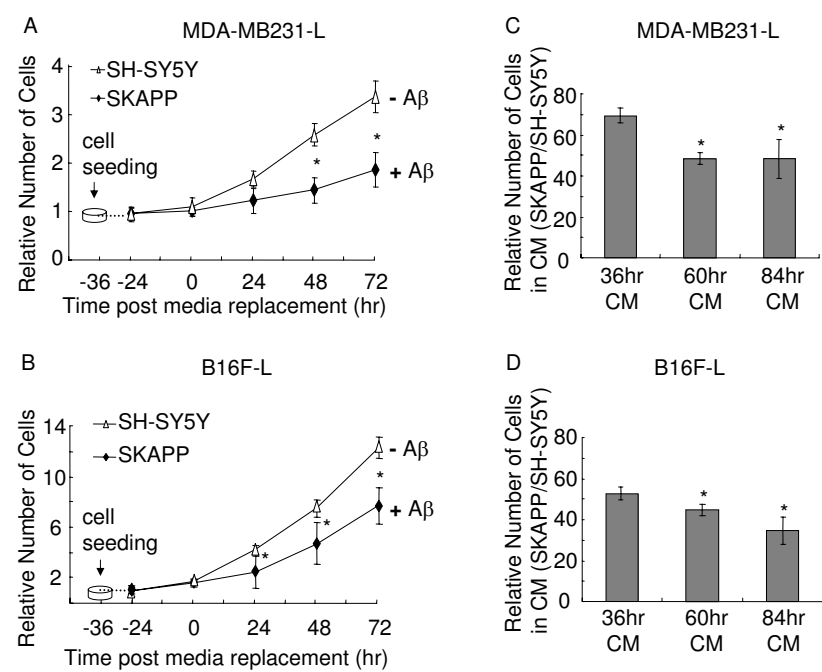

Figure 4

APP over-expressing human neuroblastoma SHSY5Y cells (SKAPP cells) had the similar inhibitory effects on the tumor cell proliferation. MDA-MB23I-L cells, BI6F-L cells (500 cells/well) and SKAPP, SKNSH cells ( 1000 cells/well) were seeded in separate 96 well plates. The number of MDA-MB23 I-L cells (A) and BI6F-L cells $(B)$ was measured by $B L I$ assay at 24, 48 and $72 \mathrm{hr}$ after incubation of $36 \mathrm{hr}-\mathrm{CM}$ from SKAPP or SH-SY5Y cells. The media from SKAPP cells showed significant difference in their ability to inhibit tumor cell proliferation compared to the media from control SH-SY5Y cells, as indicated by $* P<0.05$. (C and D) SKAPP and control SKNSH cells were grown for $36 \mathrm{hr}, 60 \mathrm{hr}$ and $84 \mathrm{hr}$ for incubation with tumor cells. The number of tumor cells was measured by BLI assay after $24 \mathrm{hr}$ of incubation. The inhibitory effect of media on MDA-MB23 I-L cells (C) and BI6F-L cells (D) was stronger than those media from shorter period of conditioning. The difference is statistically significant, $* P<0.05$. All values represent means $\pm \operatorname{SEM}(\mathrm{n}=$ 6).

used a second-order polynomial to approximate the relationship between the cell proliferation of B16F-L and $A \beta 40$ concentrations. We sorted the $A \beta$ concentrations in the ascending order for all the three time points ( $36 \mathrm{hr}, 60$ $\mathrm{hr}$, and $84 \mathrm{hr}$ ), followed by a second-order polynomial to fit the corresponding cell proliferation of B16F-L to minimize the least-squares error. Using the derived polynomial, we calculated the cell proliferation of the tumor cell from a minimum $A \beta 40$ concentration of $26 \mathrm{pM}$ to a maximum of $172 \mathrm{pM}$ at a step size of $5 \mathrm{pM}$. The same procedure was used to perform curve-fitting for MDA-MB231-L and U87-L cell lines. Finally we used the Matlab ${ }^{\circledR}$ command "surf" to plot the cell proliferation of the three tumor cell lines as a function of the $A \beta 40$ concentration (Fig. 8A). Identical approach was used to plot the cell proliferation versus the $A \beta 42$ concentration (Fig. $8 \mathrm{~B}$ ). While three tumor cell lines exhibited different cell proliferation
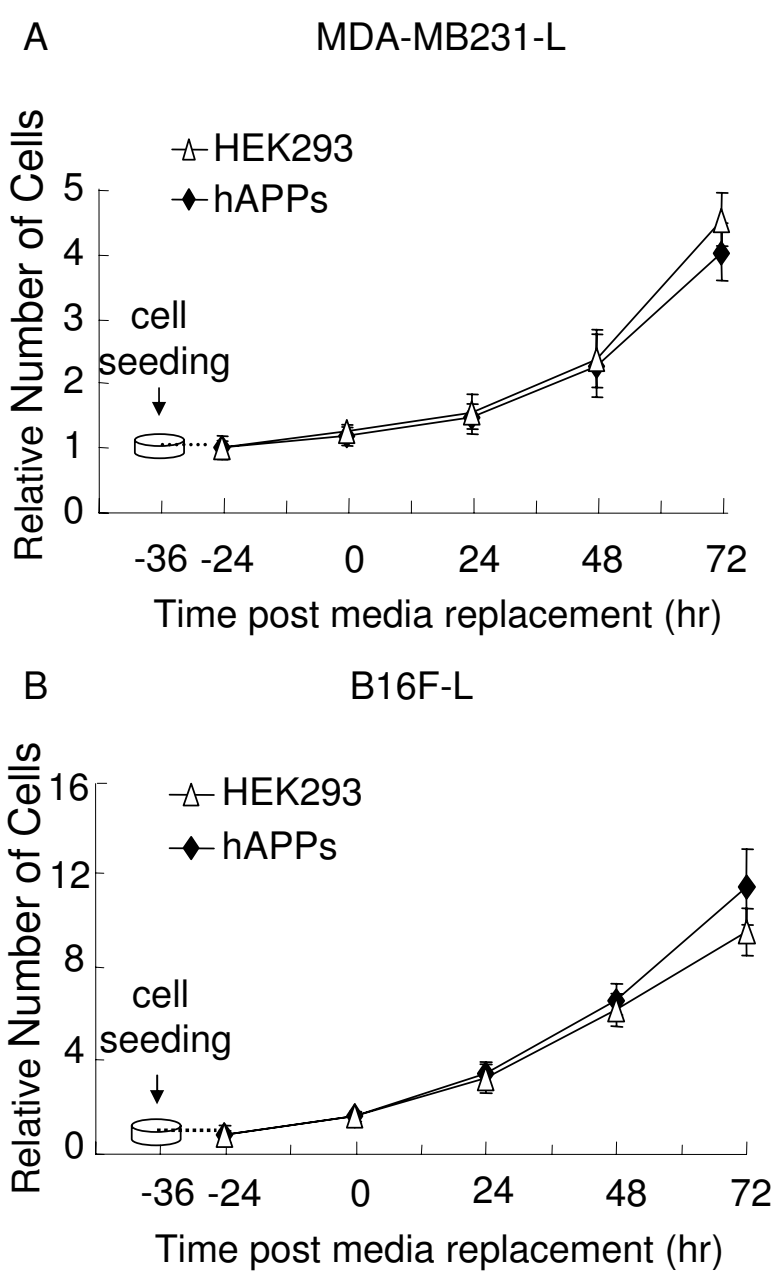

Figure 5

Lack of inhibitory effect on cell proliferation by soluble APP in CM from hAPPs expressing cells. MDAMB23 I-L cells, BI6F-L cells (500 cells/well), hAPPs and HEK 293 cells ( 1000 cells/well) were seeded in separate 96 well plates. The number of MDA-MB23I-L cells and BI6F-L cells was measured by $B L I$ assay after incubation of $36 \mathrm{hr}-\mathrm{CM}$ from hAPPs (A) or HEK293 cells (B). The media from hAPPs cells showed no significant difference in their ability to inhibit tumor cell proliferation compared to media from control HEK 293 cells. All values represent means $\pm \operatorname{SEM}(n=6)$.

at the same $A \beta$ concentrations, these tumor cells tended to have reduced cell proliferation as the concentration of $A \beta$ increased.

\section{Discussion}

The inhibitory effects on tumor cell proliferation attribute to $A \beta$ in the conditioning media of the cells over-expressing wild type or Swedish mutant APP. A $\beta$ peptides are released as soluble products from APP via a series of metabolic cleavage steps. After $36 \mathrm{hr}$ of growth, concentra- 
A

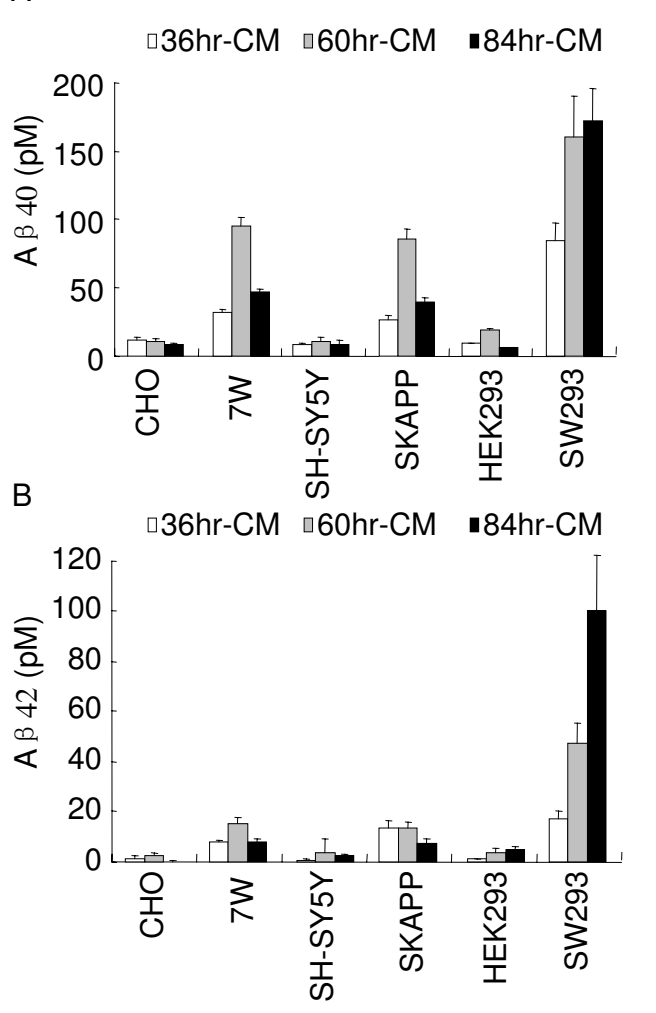

C Relative $A \beta$ levels

$\begin{array}{ll}\text { CHO } & - \\ 7 W & + \\ \text { SH-SY5Y } & - \\ \text { SKAPP } & + \\ \text { HEK293 } & - \\ \text { SW293 } & +++\end{array}$

D MDA-MB231-L

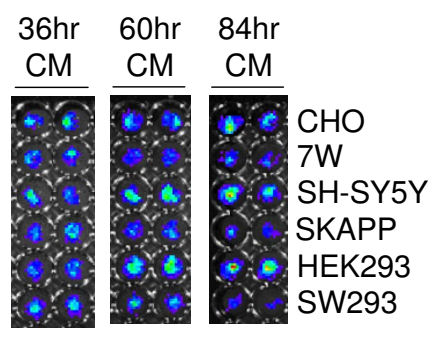

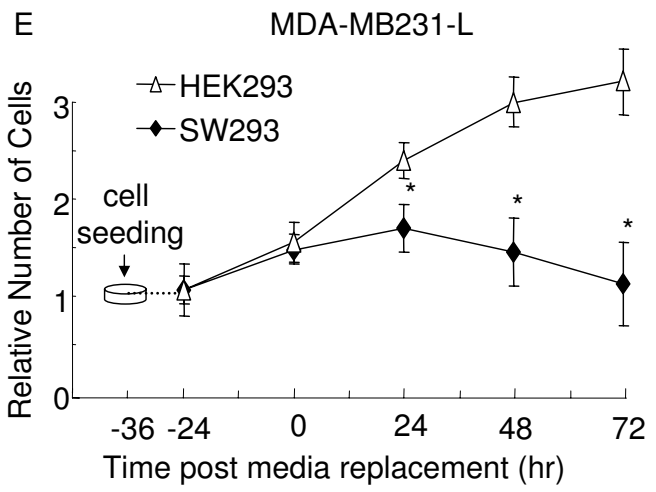

$\mathrm{F}$

B16F-L

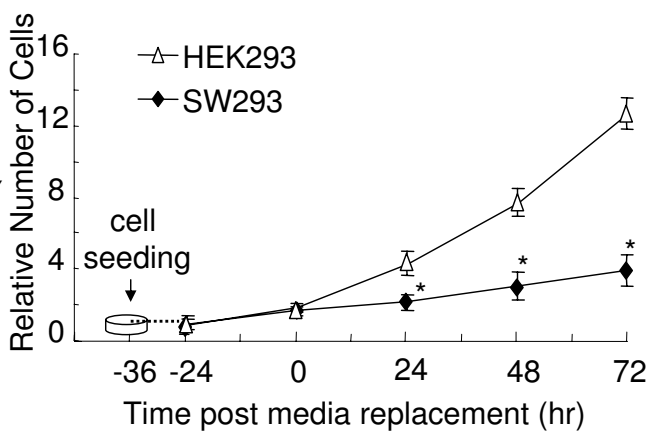

Figure 6

Inhibitory effect of CM on tumor cell proliferation correlates with A $\beta$ concentrations in the CM. (A, B) 36 hr-, 60 $\mathrm{hr}$ - and $84 \mathrm{hr}-\mathrm{CM}$ from 7W, SKAPP, SW293 and CHO, SH-SY5Y, HEK293 cells were collected, and A $\beta 40$ and A $\beta 42$ concentrations were measured by ELISA. Much more A $\beta 40$ (A) and A 342 (B) were produced by 7W, SKAPP and SW293 cells than their wild type parental cells $(P<0.05)$. The $A \beta 40$ and $A \beta 42$ concentrations in the SW293-CM were significantly higher than those in $7 \mathrm{~W}-\mathrm{CM}$ and SKAPP-CM $(P<0.05)$. All values represent means \pm SEM $(n=12)$. (C) Relative levels of $A \beta$ generated from each cell line were illustrated, based on the actual levels of $A \beta(A, B)$. (D) Representative images from MDA-MB23I-L cell cultured with $36 \mathrm{hr}, 60 \mathrm{hr}$ and $84 \mathrm{hr}$ - CM from 7W/CHO, SKAPP/SH-SY5Y and SW293/HEK293 cells. (E, F) Persistent inhibitory effect of SW293-CM on MDA-MB23I-L and BI6F-L cells proliferation. The proliferation of the MDA-MB23I-L and BI6F$L$ cells were measured by $B L I$ assay at 24,48 and $72 \mathrm{hr}$ post medium replacement. All values indicate means $\pm S E M(n=6)$, and the difference between SW293 and control HEK293 cells is statistically significant, as indicated by $*, P<0.05$.

tions of A $\beta$ in the CM of 7W, SKAPP and SW293 cells were much higher compared with their corresponding controls, CHO, SH-SY5Y, and HEK293. The inhibitory effects on the proliferation of breast and skin cancer cells were observed upon incubation with the A $\beta$ enriched $C M$ for 24 hrs. It has been shown that various species of $A \beta$ possess different degrees of cellular toxicity. Soluble $A \beta$ oligomers, including amyloid-derived diffusible ligands (ADDLs), are more neurotoxic than fibrils and insoluble larger aggregates $[32,33]$. A variety of $A \beta$ species carry different physiochemical and pharmacological properties, and soluble monomers [34], low molecular weight oligomers and ADDLs [10,35], and protofibrils [20,36] are in equilibrium with insoluble, high molecular weight fibrils [20]. A $\beta 42$ is known to be more amyloidogenic than $\mathrm{A} \beta 40$. Additional factors, such as $\mathrm{pH}$, ions $\left(\mathrm{Cu}^{2+}\right.$, $\mathrm{Fe}^{2+}, \mathrm{Zn}^{2+}$ ) also influence the aggregation process [37-40]. In this study, it is expected that there was $A \beta$ heterogeneity in aggregation states in the final CM. Our ELISA only detects soluble monomeric $A \beta$ and cannot quantify the aggregated $A \beta$ species. Therefore, it is difficult to determine the exact species that played the dominant inhibitory effects on the tumor cell proliferation. However, it is well known that synthetic $A \beta$ peptides added in growth media are notoriously heterogeneous due to variable preparation conditions, and the status of $\mathrm{A} \beta$ peptide would continuously change during the cancer cell treatment period as they would oligomerize and aggregate. 

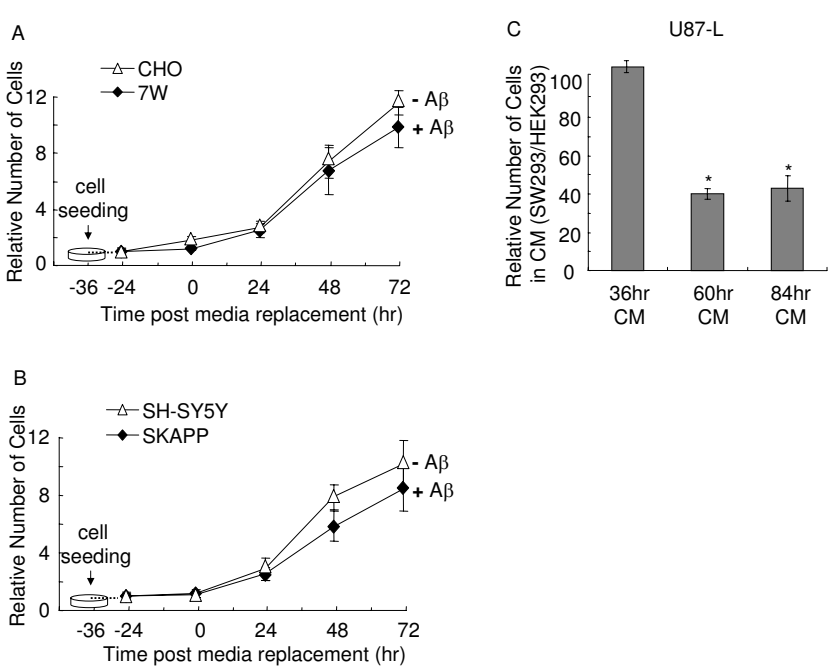

\section{Figure 7}

Proliferation of human neuroblastoma cells (U87-L) is attenuated by conditioned media with high $A \beta$ levels. U87-L cells ( 500 cells/well) and 7W/CHO, SKAPP/SHSY5Y, SW293/HEK293 cells (I 000 cells/well) were seeded in separate 96 well plates. The U87-L cells were measured by BLI assay at 24, 48 and $72 \mathrm{hr}$ after incubation of $36 \mathrm{hr}-\mathrm{CM}$. No inhibitory effect was found by the $36 \mathrm{hr}-\mathrm{CM}$ from $7 \mathrm{~W}$ cells (A) and SKAPP cells (B). (C) CM were harvested after SW293 and HEK293 cells were grown for $36 \mathrm{hr}, 60 \mathrm{hr}$ and $84 \mathrm{hr}$, The inhibitory effect of $60 \mathrm{hr}$ and $84 \mathrm{hr}$ SW293 CM on U87-L cells was stronger than the ability of $36 \mathrm{hr}-\mathrm{CM}$. All values represent means $\pm \operatorname{SEM}(n=6)$, and the difference is statistically significant, $* P<0.05$ compared with $36 \mathrm{hr}-\mathrm{CM}$.

Therefore, naturally synthesized, cultured cell derived $A \beta$ peptides have been used in our experiments, and this approach has been widely used for $\mathrm{A} \beta$ toxicity studies in AD research $[10,41,42]$.

The CM naturally secreted from APP overexpressing cells contained substantial amounts of monomeric $A \beta$ and some oligomeric $A \beta$. In viewing of the $A \beta$ concentrations in the CM of 7W, SKAPP and SW293 cells, which showed a marked increase paralleled with the growth period up to $60 \mathrm{hrs}$ and no further increase up to $84 \mathrm{hrs}$ (except for $\mathrm{A} \beta 42$ from SW293 cells), it is possible that the soluble $A \beta$ might aggregate into insoluble compositions as more monomeric $\mathrm{A} \beta$ was secreted from the cells during the extended conditioning period. We found a stronger inhibition of the tumor cells proliferation by the $60 \mathrm{hr}-\mathrm{CM}$, compared to the effect by the $36 \mathrm{hr}-\mathrm{CM}$. The CM from SW293 cells had stronger inhibition of the MDA-MB231$\mathrm{L}$ and B16F-L cells than the $60 \mathrm{hr}-\mathrm{CM}$. Meantime, we noticed that the media conditioned with three APP over expressing cells for $36 \mathrm{hrs}$ had a persistent inhibition on tumor cell proliferation. The inhibitory effects on MDA-
MB231-L and B16F-L cells became more prominent when the tumor cells were incubated with $\mathrm{CM}$ for a longer period. These $A \beta$ species caused an inhibition of tumor cell growth at different time points, whereas $\mathrm{CM}$ of untransfected cells had no effect, indicating that both monomeric and oligomeric $A \beta$ are responsible for the specific

effect.

Since it is still controversial whether $A \beta$ induced toxicity is cell type dependent [43], we adopted three tumor cell lines from different sources, the human breast cancer cell MDA-MB231, GBM cell U87, and mouse melanoma cell B16F. The MDA-MB231 and B16F cells showed high sensitivities to $A \beta$ in the $C M$. The cell proliferation of U87, however, was attenuated only by the media with high level of $A \beta$. Although $A \beta$ circulates in peripheral organs through the whole body, it is equally important to examine any effect of $A \beta$ containing CM on brain tumor cells due to the fact that $A \beta$ accumulates extensively in brains of AD patients. Our results have demonstrated that naturally secreted $A \beta$ from mammalian cells directly inhibit the proliferation of tumor cells. It is not clear whether any $\mathrm{A} \beta$ receptors at cell surface facilitate the process, as microglia cells have been reported to promote receptor dependent $A \beta$ uptake [44]. Previous studies have shown that Gprotein-coupled formyl peptide receptor like 1 in glial cells mediates the uptake of its agonist $\mathrm{A} \beta 42$, and this process could be activated by other ligands [45]. For example, CpG-containing oligodeoxynucleotide, a Tolllike receptor 9 ligand, increases the expression and activity of formyl peptide receptor that leads to enhanced endocytosis of $A \beta$ [45]. It is likely that a portion of $A \beta$ in the conditioned media was endocytosed by U87 for subsequent degradation, which reduced the effect of $A \beta$ on cell proliferation.

Our studies have taken advantage of the cell-based BLI assay that allows us to rapidly measure cell proliferation with excellent sensitivity at a high throughput scale. Although it requires luciferase expressing cell lines to examine the property of cell colonies, it is a powerful approach to estimate cell growth with great flexibility, e.g., it can be used for primary screening of the cytostatic activity of compounds.

Although our results would suggest that $\mathrm{AD}$ patients might be at lower risk for cancer occurrence, there is no strategy to overcome the risk of having $\mathrm{AD}$ by increasing $A \beta$ levels in a hope to decrease the chance of cancer formation. In addition, these findings are obtained from cultured cells in vitro, while the micro-environment for tumor growth is more complicated in vivo. Therefore, simply modulating $\mathrm{A} \beta$ levels does not seem to be a solution for inhibiting tumor growth. 

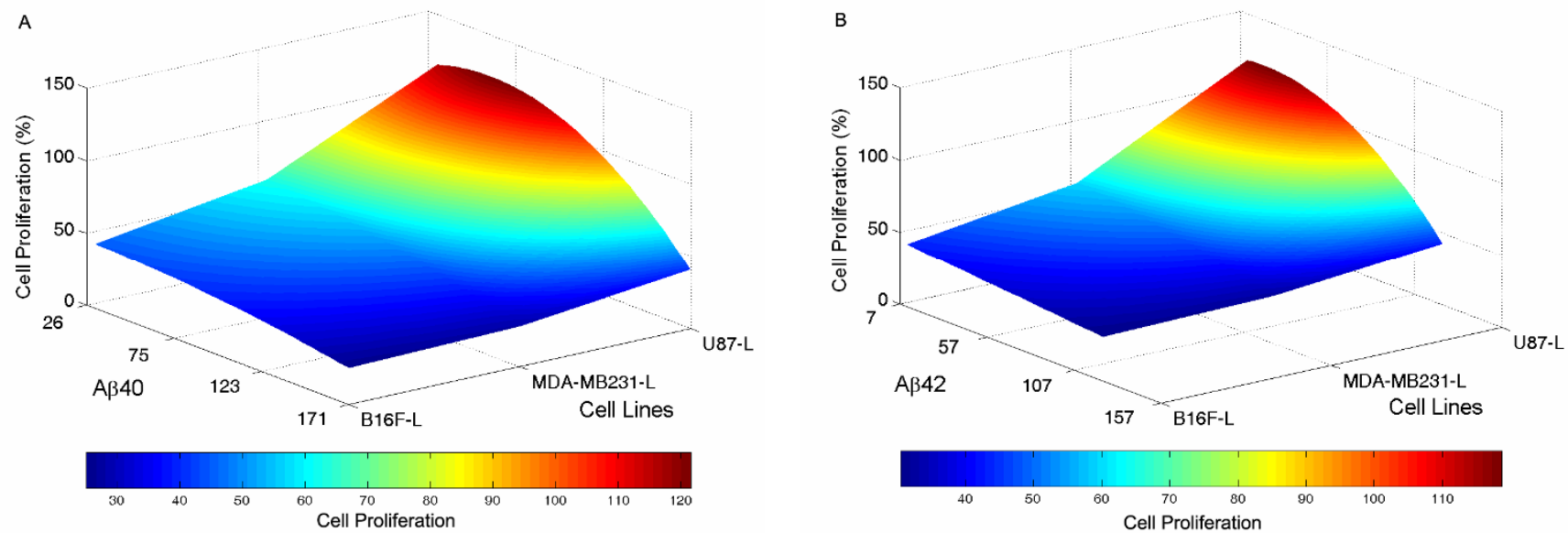

\section{Figure 8}

Surface plots of tumor cell proliferation versus the concentration of $A \beta 40$ and $A \beta 42$ in the $C M$. Second-order polynomial was used to approximate the relationship between the tumor cell proliferation and $A \beta 40(A), A \beta 42$ (B) concentrations. Using the derived polynomial, the tumor cell proliferation from minimum $A \beta 40$ and $A \beta 42$ concentrations to maximum concentrations at a step size of 5 was calculated. The Matlab ${ }^{\circledR}$ command "surf" was used to plot the proliferation of three tumor cell lines as a function of the $A \beta 40$ and $A \beta 42$ concentrations. The region of high cell proliferation (red zone) lies at low A $\beta$ concentrations.

Nevertheless, understanding the association of $\mathrm{A} \beta$ with tumorigenesis is critical for the elucidation of molecular pathways related to cell proliferation. The key enzyme for the generation of $A \beta$, the $\gamma$-secretase, is the target not only for Alzheimer's disease but also for human T cell acute lymphoblastic leukemia [46]. While chemotherapy increases the activity and expression of the $\gamma$-secretase complex, the $\gamma$-secretase inhibitor renders colon cancer cells more sensitive to chemotherapy [47]. Importantly, the $\gamma$-secretase cleavage of APP generates two products, A $\beta$ and the amyloid intracellular domain (AICD), the latter to be found as a regulator of EGF receptor at the transcription level [48]. EGF receptor is up-regulated in many types of tumors, therefore, both AICD and EGF receptor are explored at targets for cancer therapy. Furthermore, enhanced $\gamma$-secretase cleavage of APP leads to increased generation of APP C-terminal fragments, $A \beta$ and AICD. It is conceivable that alteration of downstream gene expression caused by increased APP C-terminal fragments and AICD may lead to changes in proteins secreted to the conditioned media. Whether those novel factors inhibit cell proliferation awaits further exploration.

\section{Conclusion}

This study provides evidence that naturally secreted $A \beta$ inhibit the proliferation of cultured GBM, breast cancer, and skin cancer cells. Understanding the mechanism underlying the effects of $A \beta$ on tumor cell proliferation would provide new pathways downstream of $A \beta$ that may bind to putative tumor cell surface receptors. Identifica- tion of these pathways will reveal novel targets for therapeutic intervention of tumor cell growth.

\section{Abbreviations}

AD: Alzheimer disease; $A \beta$ : amyloid- $\beta$ protein; APP: amyloid precursor protein; GBM: glioblastoma multiforme; AICD: APP intracellular domain; BLI: bioluminescence imaging; CHO: Chinese hamster ovary; HEK293: human embryonic kidney 293 cells; CM: conditioning media; ROI: region of interest; ADDLs: amyloid-derived diffusible ligands.

\section{Competing interests}

The authors declare that they have no competing interests.

\section{Authors' contributions}

$\mathrm{HZ}$ carried out cell culture experiments, HZ, JZ, XX, KC, and KW carried out BLI analyses, MO carried out $\mathrm{A} \beta$ measurements, HZ, SK, WX and SW participated in the design of the study, HZ, WX and SW conceived of the study and draft the manuscript. All authors read and approved the final manuscript.

\section{Acknowledgements}

The BI6F-L cell was a gift from Dr. Noah Craft in Harbor-UCLA Medical Center. This work is funded by a NIH Human Brain Project T32 training grant to JZ, grants from the Harvard Center for Neurodegeneration and Repair to HZ, ZJ, XX, KW, and SW, NIH grant AG0I5379 to WX, and grants from Ellison Foundation, NIH ROI LM008689, NIH ROI AG028928 and NIH ROI LM00916I to SW. 


\section{References}

I. Kawas $\mathrm{CH}$, Katzman R: Epidemiology of dementia and Alzheimer disease. In Alzheimer Disease 2nd edition. Edited by: Terry RD, Katzman R, Bick KL, Sisodia SS. Philadelphia, Philly: Lippincott Williams \& Wilkins; 1999:95-II6.

2. Radhakrishnan K, Mokri B, Parisi JE, O'Fallon WM, Sunku J, Kurland LT: The trends in incidence of primary brain tumors in the population of Rochester, Minnesota. Ann Neurol 1995 , 37(I):67-73

3. Molsa PK, Marttila RJ, Rinne UK: Survival and cause of death in Alzheimer's disease and multi-infarct dementia. Acta Neurol Scand 1986, 74(2): 103-107.

4. Beard CM, Kokmen E, Sigler C, Smith GE, Petterson T, O'Brien PC: Cause of death in Alzheimer's disease. Ann Epidemiol 1996, 6(3): 195-200.

5. Yamada M, Sasaki H, Mimori Y, Kasagi F, Sudoh S, Ikeda J, Hosoda Y, Nakamura S, Kodama K: Prevalence and risks of dementia in the Japanese population: RERF's adult health study Hiroshima subjects. Radiation Effects Research Foundation. I Am Geriatr Soc 1999, 47(2): 189-195

6. Selkoe DJ: Alzheimer disease: mechanistic understanding predicts novel therapies. Ann Intern Med 2004, I40(8):627-638.

7. Drouet B, Pincon-Raymond M, Chambaz J, Pillot T: Molecular basis of Alzheimer's disease. Cell Mol Life Sci 2000, 57(5):705-7I 5.

8. Hardy J, Selkoe DJ: The amyloid hypothesis of Alzheimer's disease: progress and problems on the road to therapeutics. Science 2002, 297(5580):353-356

9. Rao KS, Hegde ML, Anitha S, Musicco M, Zucca FA, Turro NJ, Zecca $\mathrm{L}$ : Amyloid beta and neuromelanin-toxic or protective molecules? The cellular context makes the difference. Prog Neurobiol 2006, 78(6):364-373.

10. Walsh DM, Klyubin I, Fadeeva JV, Cullen WK, Anwyl R, Wolfe MS Rowan MJ, Selkoe DJ: Naturally secreted oligomers of amyloid beta protein potently inhibit hippocampal long-term potentiation in vivo. Nature 2002, 4 I 6(6880):535-539.

II. Rottkamp CA, Atwood CS, Joseph JA, Nunomura A, Perry G, Smith MA: The state versus amyloid-beta: the trial of the most wanted criminal in Alzheimer disease. Peptides 2002 23(7): |333-|34|

12. Obrenovich ME, Joseph JA, Atwood CS, Perry G, Smith MA: Amyloid-beta: a (life) preserver for the brain. Neurobiol Aging 2002 23(6): 1097-1099.

13. Gabuzda D, Busciglio J, Chen LB, Matsudaira P, Yankner BA: Inhibition of energy metabolism alters the processing of amyloid precursor protein and induces a potentially amyloidogenic derivative. J Biol Chem 1994, 269( I 8): I 3623-I3628.

14. Mattson MP, Pedersen WA: Effects of amyloid precursor protein derivatives and oxidative stress on basal forebrain cholinergic systems in Alzheimer's disease. Int J Dev Neurosci 1998, I 6(7-8):737-753.

15. Frederikse PH, Garland D, Zigler JS Jr, Piatigorsky J: Oxidative stress increases production of beta-amyloid precursor protein and beta-amyloid (Abeta) in mammalian lenses, and Abeta has toxic effects on lens epithelial cells. J Biol Chem I996, 27I(I7): 10169-10174.

16. Misonou H, Morishima-Kawashima M, lhara $Y$ : Oxidative stress induces intracellular accumulation of amyloid beta-protein (Abeta) in human neuroblastoma cells. Biochemistry 2000, 39(23):6951-6959.

17. Paola D, Domenicotti C, Nitti M, Vitali A, Borghi R, Cottalasso D Zaccheo D, Odetti P, Strocchi P, Marinari UM, et al.: Oxidative stress induces increase in intracellular amyloid beta-protein production and selective activation of betal and betall PKCs in NT2 cells. Biochem Biophys Res Commun 2000, 268(2):642-646.

18. Nakagawa T, Kabuto M, Kubota T, Kodera T, Sato K: Production of amyloid beta protein precursor as a proteinase inhibitor by human astrocytic tumors. Anticancer Res 1999, I 9(4B):2963-2968.

19. Paris D, Townsend K, Quadros A, Humphrey J, Sun J, Brem S, Wotoczek-Obadia M, DelleDonne A, Patel N, Obregon DF, et al.: Inhibition of angiogenesis by Abeta peptides. Angiogenesis 2004 7(I):75-85.

20. Walsh DM, Hartley DM, Kusumoto Y, Fezoui Y, Condron MM, Lomakin A, Benedek GB, Selkoe DJ, Teplow DB: Amyloid betaprotein fibrillogenesis. Structure and biological activity of protofibrillar intermediates. I Biol Chem 1999. 274(36):25945-25952

21. Sadikot RT, Blackwell TS: Bioluminescence imaging. Proc Am Thorac Soc 2005, 2(6):537-540

22. Contag $\mathrm{CH}$, Bachmann $\mathrm{MH}$ : Advances in in vivo bioluminescence imaging of gene expression. Annu Rev Biomed Eng 2002, 4:235-260.

23. Rubin JB, Kung AL, Klein RS, Chan JA, Sun Y, Schmidt K, Kieran MW, Luster AD, Segal RA: A small-molecule antagonist of CXCR4 inhibits intracranial growth of primary brain tumors. Proc Natl Acad Sci USA 2003, I00(23): I3513-13518

24. Craft N, Bruhn KW, Nguyen BD, Prins R, Liau LM, Collisson EA, De A, Kolodney MS, Gambhir SS, Miller JF: Bioluminescent imaging of melanoma in live mice. I Invest Dermatol 2005, I 25(I): I59-165.

25. Citron M, Diehl T, Gordon G, Biere A, Seubert P, Selkoe D: Evidence that Ab42 and Ab40 are generated from the b-amyloid precursor protein by different protease activities. Proc Natl Acad Sci USA 1996, 93: I3170-13175.

26. Xia W, Zhang J, Perez R, Koo EH, Selkoe DJ: Interaction between amyloid precursor protein and presenilins in mammalian cells: implications for the pathogenesis of Alzheimer disease. Proc Natl Acad Sci USA 1997, 94( I 5):8208-82 I3.

27. Hung AY, Selkoe DJ: Selective ectodomain phosphorylation and regulated cleavage of $\beta$-amyloid precursor protein. EMBO J 1994, 13:534-542.

28. Citron M, Oltersdorf T, Haass C, McConlogue L, Hung AY, Seubert P, Vigo-Pelfrey C, Lieberburg I, Selkoe DJ: Mutation of the $\beta$-amyloid precursor protein in familial Alzheimer's disease increases $\beta$-protein production. Nature 1992, 360:672-674

29. Seubert P, Vigo-Pelfrey C, Esch F, Lee M, Dovey H, Davis D, Sinha S, Schlossmacher M, Whaley J, Swindlehurst C, et al:: Isolation and quantification of soluble Alzheimer's beta-peptide from biological fluids. Nature 1992, 359(6393):325-327.

30. Cui $\mathrm{K}, \mathrm{Xu} X$, Zhao $\mathrm{H}$, Wong ST: A quantitative study of factors affecting in vivo bioluminescence imaging. Luminescence 2008 , 23(5):292-295.

31. Xia W, Zhang J, Kholodenko D, Citron M, Podlisny MB, Teplow DB, Haass C, Seubert P, Koo EH, Selkoe DJ: Enhanced production and oligomerization of the 42-residue amyloid beta-protein by Chinese hamster ovary cells stably expressing mutant presenilins. J Biol Chem 1997, 272( I 2):7977-7982.

32. Dahlgren KN, Manelli AM, Stine WB Jr, Baker LK, Krafft GA, LaDu $M J$ : Oligomeric and fibrillar species of amyloid-beta peptides differentially affect neuronal viability. J Biol Chem 2002, 277(35):32046-32053

33. Gong Y, Chang L, Viola KL, Lacor PN, Lambert MP, Finch CE, Krafft GA, Klein WL: Alzheimer's disease-affected brain: presence of oligomeric A beta ligands (ADDLs) suggests a molecular basis for reversible memory loss. Proc Natl Acad Sci USA 2003 I 00( I 8): I 04I7-10422. Epub 12003 Aug 10418

34. Taylor BM, Sarver RW, Fici G, Poorman RA, Lutzke BS, Molinari A, Kawabe T, Kappenman K, Buhl AE, Epps DE: Spontaneous aggregation and cytotoxicity of the beta-amyloid Abetal-40: a kinetic model. J Protein Chem 2003, 22(I):3 I-40.

35. Bitan G, Kirkitadze MD, Lomakin A, Vollers SS, Benedek GB, Teplow DB: Amyloid beta -protein (Abeta) assembly: Abeta 40 and Abeta 42 oligomerize through distinct pathways. Proc Nat Acad Sci USA 2003, I 00(I):330-335.

36. Harper JD, Wong SS, Lieber CM, Lansbury PT Jr: Observation of metastable $A \beta$ amyloid protofibrils by atomic force microscopy. Chem \& Biol 1997, 4(2): I 19-125.

37. Barrow CJ, Zagorski MG: Solution structures of beta peptide and its constituent fragments: relation to amyloid deposition. Science 199|, 253(5016): |79-182.

38. Mantyh PW, Ghilardi JR, Rogers S, Demaster E, Allen CJ, Stimson ER, Maggio JE: Aluminum, iron, and zinc ions promote aggregation of physiological concentrations of beta-amyloid peptide. | Neurochem 1993, 6 I(3): I |7|-| | 74

39. Atwood CS, Moir RD, Huang X, Scarpa RC, Bacarra NM, Romano DM, Hartshorn MA, Tanzi RE, Bush Al: Dramatic aggregation of Alzheimer abeta by $\mathrm{Cu}(\mathrm{II})$ is induced by conditions representing physiological acidosis. I Biol Chem 1998 273(2I): $12817-12826$.

40. Klug GM, Losic D, Subasinghe SS, Aguilar MI, Martin LL, Small DH: Beta-amyloid protein oligomers induced by metal ions and 
acid $\mathrm{pH}$ are distinct from those generated by slow spontaneous ageing at neutral pH. Eur J Biochem 2003, 270(2I):4282-4293.

4I. Walsh DM, Townsend M, Podlisny MB, Shankar GM, Fadeeva JV, Agnaf OE, Hartley DM, Selkoe DJ: Certain inhibitors of synthetic amyloid beta-peptide (Abeta) fibrillogenesis block oligomerization of natural Abeta and thereby rescue long-term potentiation. J Neurosci 2005, 25( ( 0):2455-2462.

42. Townsend M, Mehta T, Selkoe DJ: Soluble Abeta inhibits specific signal transduction cascades common to the insulin receptor pathway. J Biol Chem 2007, 282(46):33305-333I2.

43. Gschwind M, Huber G: Apoptotic cell death induced by betaamyloid I-42 peptide is cell type dependent. I Neurochem 1995, 65(I):292-300.

44. Chen K, Iribarren P, Hu J, Chen J, Gong W, Cho EH, Lockett S, Dunlop NM, Wang JM: Activation of Toll-like receptor 2 on microglia promotes cell uptake of Alzheimer disease-associated amyloid beta peptide. J Biol Chem 2006, 28 I(6):365I-3659.

45. Iribarren P, Chen K, Hu J, Gong W, Cho EH, Lockett S, Uranchimeg $\mathrm{B}$, Wang JM: CpG-containing oligodeoxynucleotide promotes microglial cell uptake of amyloid beta $\mathrm{I}-42$ peptide by upregulating the expression of the G-protein- coupled receptor mFPR2. Faseb / 2005, I 9( | 4):2032-2034.

46. Lewis HD, Leveridge M, Strack PR, Haldon CD, O'Neil J, Kim H, Madin A, Hannam JC, Look AT, Kohl N, et al.: Apoptosis in T cell acute lymphoblastic leukemia cells after cell cycle arrest induced by pharmacological inhibition of notch signaling. Chem Biol 2007, I 4(2):209-219.

47. Meng RD, Shelton CC, Li YM, Qin LX, Notterman D, Paty PB, Schwartz GK: gamma-Secretase inhibitors abrogate oxaliplatin-induced activation of the Notch-I signaling pathway in colon cancer cells resulting in enhanced chemosensitivity. Cancer Res 2009, 69(2):573-582.

48. Zhang YW, Wang R, Liu Q, Zhang H, Liao FF, Xu H: Presenilin/ \{gamma\}-secretase-dependent processing of beta-amyloid precursor protein regulates EGF receptor expression. Proc Natl Acad Sci USA 2007, 104(25):106|3-10618.

Publish with Bio Med Central and every scientist can read your work free of charge

"BioMed Central will be the most significant development for disseminating the results of biomedical research in our lifetime. "

Sir Paul Nurse, Cancer Research UK

Your research papers will be:

- available free of charge to the entire biomedical community

- peer reviewed and published immediately upon acceptance

- cited in PubMed and archived on PubMed Central

- yours - you keep the copyright

Submit your manuscript here:

http://www.biomedcentral.com/info/publishing_adv.asp
BioMedcentral 